\title{
POLA ASUH AYAH TERHADAP ANAK PEREMPUAN DAN ANAK LAKI-LAKI KELUARGA PATRILINEAL
}

\author{
Katherine Paramitha ${ }^{1}$, Debora Basaria ${ }^{2}$ \\ ${ }^{1}$ Fakultas Psikologi Universitas Tarumanagara, Jakarta \\ Email: katherine.paramitha@gmail.com \\ ${ }^{2}$ Fakultas Psikologi, Universitas Tarumanagara, Jakarta \\ Email: deborabasariayulianti@gmail.com
}

\begin{abstract}
ABSTRAK
In Indonesia, there are 1128 ethnic groups that can be divided into 2 according to lineage system, that is matrilineal and patrilineal. In patrilineal families, family name, property and others are passed down through sons. The characteristics of patrilineal families showed bias and favor towards sons. The goal of this research is to provide a description of father's parenting style towards daughters and sons in patrilineal families. This research used a descriptive research method with Baumrind's parenting style as the grand theory. The data collection process starts from April till May to 201 fathers using a parenting style questionnaire from Tarumanagara University's Department of Psychology. The result of this research shows that $84.6 \%$ of the total fathers applied the same kind of parenting style towards their sons and daughters. These fathers no longer differentiate between daughters and sons. 92.9\% of these fathers applied authoritative parenting styles to both daughters and sons. A small portion of the participant, 15.4\% of 201 participants applied different parenting style towards their daughters and sons. These fathers applied authoritative parenting style towards their daughters and permissive parenting style towards their sons.
\end{abstract}

Kata kunci: fatherhood, parenting styles, patrilineal family, daughter, son

\section{PENDAHULUAN}

\section{Latar Belakang}

Terdapat 2 macam garis kekeluargaan, yaitu matrilineal dan patrilineal. Di Indonesia, keluarga patrilineal menjadi lebih umum. Patrilineal merupakan garis keturunan ayah, dengan karakteristik nama keluarga, properti, harta dan lain-lain diwariskan lewat anak laki-laki (Ruether, 2007). Salah satu ciri-ciri dari keluarga patrilineal menurut Ruether dalam buku Encyclopedia of Sex and Gender adalah kehadiran anak laki-laki lebih diinginkan dibandingkan anak perempuan. Dalam keluarga patrilineal kehadiran anak laki-laki sangat diharapkan, jika tidak keluarga dapat dikatakan punah (Vergouwen dalam Aninda, 2013). Ada pandangan pula yang menyebutkan bahwa keluarga yang tidak memiliki anak laki-laki dalam keluarganya seperti pohon yang tanpa akar, karena anak laki-laki juga berkewajiban untuk mengurus dan meneruskan kelangsungan hidup keluarganya (Nurelide dalam Aninda, 2013).

Salah satu contoh keluarga patrilineal adalah keluarga Tionghoa. Pada sistem kekerabatan petrilineal pada keluarga Tionghoa nama keluarga diturunkan sebagai garis keturunan ayah, sehingga peran ayah dan abak laki-laki sangat penting. Anak laki-laki tertua akan menggantikan kedudukan ayah sebagai kepala keluarga bila ayahnya meninggal dunia, dan dia pula yang akan menerima warisan paling banyak dibandingkan saudara laki-laki lainnya. Dalam keluarga Tionghoa totok, anak wanita tidak mendapatkan warisan karena setelah menikah dia akan mengikuti dan menjadi tanggung jawab keluarga suaminya. Selain itu yang berhak untuk mengurus dan memelihara abu leluhur serta melaksanakan upacara penghormatan terhadap arwah leluhur adalah anak laki-laki (Suliyati, 2002). 
Pada masa yang lalu wanita di lingkungan keluarga Tionghoa bila sudah memasuki usia dewasa, mereka dipingit dan tidak bebas lagi melakukan kegiatan di luar rumah sampai saat mereka menikah. Tradisi ini menyebabkan wanita Tionghoa tidak mendapatkan pendidikan yang memadai. Mereka hanya mendapat pendidikan dari keluarga yang berkaitan dengan dengan pendidikan moral, budaya, tradisi, agama dan hal-hal yang berkaitan dengan pengelolaan rumah tangga dan keluarga. Hal ini berbeda dengan laki-laki yang mendapat kebebasan dalam memperoleh pendidikan (Suliyati, 2002).

Namun pada masa sekarang, masyarakat Tionghoa berbaur dengan masyarakat yang lebih heterogen dan banyak dari mereka yang telah menempuh pendidikan barat, sehingga mereka memandang kedudukan anak perempuan sama pentingnya dengan anak laki-laki. Dengan demikian tidak ada perlakuan istimewa untuk anak laki-laki. Kemungkinan terjadinya perceraian karena istri tidak dapat melahirkan anak laki-laki sangat kecil. Pendidikan membawa dampak pada lingkungan masyarakat Tionghoa sekarang yaitu bahwa kekuasaan politik, ekonomi dan sosial terbagi rata antara laki-laki dan perempuan. Dalam hal hak waris, anak perempuan mendapat hak waris sama besarnya seperti anak laki-laki. Di dalam keluarga pun, tidak ada pembagian yang tegas dalam tugas yang harus ditangani laki-laki atau perempuan. Laki-laki (ayah) dapat melakukan tugas-tugas domestik yang meliputi tugas kerumahtanggaan dan perempuan (ibu) dapat melakukan tugas-tugas di luar rumah. Yang lebih diutamakan dalam keluarga adalah keharmonisan lahir dan batin (Suliyati, 2002).

Menurut Suliyati, para keluarga Tionghoa di Indonesia sudah tidak memperlihatkan adanya bias kepada anak laki-laki. Namun, terdapat jurnal yang menunjukkan hal yang tidak sesuai dengan penemuan Suliyati, dimana masih terdapat bias terhadap anak laki-laki. Terdapat sebuah penelitian yang dilakukan oleh Floyd pada tahun 2013 mengenai nilai-nilai keluarga patrilineal di dua komunitas Songshan dan Da-An di Taiwan dengan sosioekonomi yang berbeda dan masih terus terus menempatkan kepentingan besar pada ahli waris laki-laki, menjaga patrilineal sebagai ideal, dan mengantisipasi untuk dirawat oleh anak laki-laki yang sudah menikah di usia tua (Lee \& Sun dalam Floyd, 2013). Terdapat sebuah penelitian yang dilakukan oleh Floyd pada tahun 2013 mengenai nilai-nilai keluarga patrilineal di dua komunitas Songshan dan Da-An di Taiwan dengan sosioekonomi yang berbeda dan masih terus terus menempatkan kepentingan besar pada ahli waris laki-laki, menjaga patrilineal sebagai ideal, dan mengantisipasi untuk dirawat oleh anak laki-laki yang sudah menikah di usia tua (Lee \& Sun dalam Floyd, 2013). Di daerah Da-An 36,4\% (63 dari 173) tidak memiliki anak perempuan, tetapi hanya 18,5\% (32 dari 173) tidak memiliki anak laki-laki. Di daerah Songshan persentase masing-masing adalah 35,6\% (32 dari 90) dan 14,4\% (13 dari 90) (Floyd, 2003).

Ayah memiliki konstruk sebagai pemberi nafkah, hal ini dapat ditelusuri dari transformasi fatherhood yang dimulai ketika ayah harus menjadi pemilik properti agar dapat menjalankan peran sebagai seorang ayah. Anak-anak yang memiliki ayah yang tidak memiliki tanah akan ditempatkan di keluarga yang dipimpin oleh pria yang memiliki tanah. Kepala keluarga ini menerima anak tersebut sebagai keluarga mereka bersama-sama dengan anak kandung mereka, yang menjadikan fatherhood sebagai hak khusus dari pria yang memiliki tanah. Ayah kemudian berubah menjadi ayah yang menjadi pemberi nafkah. Fatherhood dihubungkan dengan pernikahan dan maskulinitas. Ayah sebagai pemberi nafkah diharapkan dapat bekerja sehingga mengakibatkan ayah yang terpisah dengan anak-anaknya (Sánchez, 2017).

Di Indonesia, ditemukan fenomena-fenomena mengenai perbedaan pola asuh yang diterapkan oleh ayah kepada anak perempuan dan anak laki-laki, namun ada pula ayah yang mampu menerapkan pola asuh yang sama kepada anak perempuan dan anak laki-laki. 
Terkait dengan pengasuhan orangtua, terdapat dua dimensi tipe pengasuhan orangtua yang muncul secara konsisten yaitu acceptance-responsiveness, yang mengacu pada perilaku positif yang terkait dengan penerimaan dan kehangatan, dan perilaku negatif seperti penolakan dan kritik; dan demandingness-control, yang mengacu pada perilaku negatif seperti kontrol orangtua dan overprotection, dan perilaku positif seperti promosi otonomi (Sigelman \& Rider, 2012). Dari 2 dimensi ini, pola asuh dapat dikategorikan menjadi 3 yaitu, authoritarian parenting adalah gaya pengasuhan yang ketat yang menggabungkan demandingness-control yang tinggi dan rendah acceptance-responsiveness; permissive parenting adalah pola asuh yang tinggi dalam acceptance-responsiveness namun rendah dalam demandingness-control; dan authoritative parenting adalah pola asuh yang lebih fleksibel, dimana mereka menuntut dan melakukan kontrol, tetapi mereka juga menerima dan responsif (Sigelman \& Rider, 2012).

Pola asuh authoritative terdiri dari sikap responsif dan control yang adekuat dari orang tua, yang memfasilitasi perkembangan perilaku anak secara kompeten dan optimal. Pola asuh ini biasanya terlihat dari penggunaan teknik induktif dan suportif dalam pengasuhan anak. Sebaliknya, pola asuh authoritarian bersifat mengatur dan menolak anak, mereka sering menggunakan kekuatan dengan tegas, membatasi dan menggunakan strategi hukuman dan menekankan kepatuhan penuh dari seorang anak. (Sangawi, Adams \& Reissland, 2015)

Pada keluarga patrilineal masa lalu, terlihat jelas perbedaan prioritas dan bias kepada anak lakilaki, sedangkan pada masa sekarang ditemukan hasil yang berbeda. Pada masa kini juga ditemukan fenomena yang berbeda-beda, karena terdapat perbedaan inilah, penelitian ini bertujuan untuk mengetahui apakah pola asuh ayah pada anak laki-laki dan anak perempuan berbeda di keluarga patrilineal?

\section{METODE PENELITIAN}

Partisipan penelitian. Partisipan dalam penelitian ini adalah ayah yang berasal dari keluarga patrilineal, yang berada pada rentang usia middle adulthood yaitu 40-65 tahun dan memiliki anak perempuan dan anak laki-laki yang tidak dibatasi. Partisipan yang berpartisipasi pada penelitian ini berjumlah 201 orang ayah.

Partisipan berdasarkan suku bangsa terbagi menjadi 5 kelompok yaitu Partisipan yang berasal dari suku Jawa berjumlah 76 orang (37.8\%), partisipan yang berasal dari suku Tionghoa berjumlah 63 orang (31.3\%), partisipan yang berasal dari suku Batak berjumlah 38 orang (18.9\%), partisipan yang berasal dari suku Manado berjumlah 19 orang $(9.5 \%)$ dan partisipan yang berasal dari suku Sunda berjumlah 5 orang $(2.5 \%)$.

Jenis penelitian. Penelitian ini termasuk dalam tipe penelitian deskriptif survei untuk mengetahui pola asuh ayah di keluarga patrilineal. Menurut Best, penelitian deskriptif adalah penelitian yang berhubungan dengan kondisi atau hubungan yang ada; keyakinan, poin pandangan, atau sikap yang dianut; proses yang sedang terjadi; efek yang sedang terasa; atau tren yang berkembang. (Best dalam Cohen, Manion \& Morrison, 2007).

Penelitian survei biasanya mengumpulkan data pada waktu tertentu dengan tujuan untuk menggambarkan sifat kondisi yang ada, atau mengidentifikasi standar terhadap pembandingan kondisi yang ada, atau menentukan hubungan yang ada antara peristiwa tertentu (Cohen, Manion \& Morrison, 2007). 
Alat ukur. Penelitian ini menggunakan alat ukur pola asuh yang dikembangkan oleh Fakultas Psikologi Universitas Tarumanagara yang berbentuk kuesioner. Pola asuh dibagi menjadi 2 dimensi yaitu parental responsiveness dan parental demandingness. Lalu terdapat 7 sub dimensi yaitu kehangatan, hubungan timbal balik, komunikasi yang efektif, attachment, menjalankan peraturan, menyediakan pengawasan yang konsisten dan menasehati anak jika melanggar peraturan. Kuesioner ini menggunakan skala Likert yang terdiri dari sangat tidak sesuai, tidak sesuai, ragu-ragu, sesuai dan sangat sesuai. Skor yang diberikan pada setiap jawaban adalah 1 untuk sangat tidak sesuai, 2 untuk tidak sesuai, 3 untuk ragu-ragu dan 4 untuk sesuai dan 5 untuk sangat sesuai.

\section{HASIL DAN PEMBAHASAN}

Berdasarkan pola asuh kepada anak perempuan, partisipan yang menerapkan pola asuh authoritative berjumlah 174 orang $(86.6 \%)$, partisipan yang menerapkan pola asuh authoritarian berjumlah 14 orang (7\%), dan partisipan yang menerapkan pola asuh permissive berjumlah 13 orang $(6.5 \%)$. Berdasarkan pola asuh kepada anak laki-laki, partisipan yang menerapkan pola asuh authoritative berjumlah 165 orang $(82.1 \%)$, partisipan yang menerapkan pola asuh permissive berjumlah 30 orang (14.9\%), dan partisipan yang menerapkan pola asuh authoritarian berjumlah 6 orang (3\%).

Melihat dari perbedaan pola asuh yang diterapkan partisipan kepada anak perempuan dan anak laki-lakinya, dalam penelitian ini partisipan paling banyak menerapkan pola asuh yang sama kepada baik anak perempuan dan anak laki-laki. Partisipan yang menerapkan pola asuh yang sama kepada anak perempuan dan anak laki-laki berjumlah 170 orang $(84.6 \%)$ dan partisipan yang menerapkan pola asuh yang berbeda kepada anak perempuan dan anak laki-laki berjumlah 31 orang $(15.4 \%)$.

Pada partisipan yang menerapkan pola asuh sama kepada anak perempuan dan anak laki-laki, partisipan paling banyak menerapkan pola asuh authoritative yaitu sebanyak 158 orang (92.9\%). Partisipan yang menerapkan pola asuh permissive kepada anak perempuan dan anak laki-lakinya berjumlah 9 orang $(5.3 \%)$ dan partisipan yang menerapkan pola asuh authoritarian kepada anak perempuan dan anak laki-lakinya berjumlah 3 orang $(1.8 \%)$.

Pada partisipan yang menerapkan pola asuh berbeda kepada anak perempuan dan anak laki-laki, partisipan paling banyak menrapkan pola asuh authoritative kepada anak perempuan yaitu sebanyak 16 orang (51.6\%). Partisipan yang menerapkan pola asuh authoritarian kepada anak perempuannya berjumlah 11 orang $(35.5 \%)$, partisipan yang menerapkan pola asuh permissive kepada anak perempuannya berjumlah 4 orang (12.9\%). Kepada anak laki-laki, partisipan paling banyak menerapkan pola asuh permissive yaitu sebanyak 21 orang $(67.7 \%)$. Partisipan yang menerapkan pola asuh authoritative kepada anak laki-lakinya berjumlah 7 orang (22.6\%), partisipan yang menerapkan pola asuh authoritarian kepada anak laki-lakinya berjumlah 3 orang $(9.7 \%)$.

Berdasarkan pola asuh kepada anak perempuan berdasarkan suku bangsa, ayah dari keluarga Jawa mayoritas menerapkan pola asuh authoritative kepada anak perempuannya. Ayah Jawa yang menerapkan pola asuh authoritative sebanyak 66 orang (32.8\%), ayah Jawa yang menerapkan pola asuh authoritarian sebanyak 3 orang (1.5\%), dan ayah Jawa yang menerapkan pola asuh permissive sebanyak 7 orang (3.5\%).

Ayah dari keluarga Batak mayoritas menerapkan pola asuh authoritative kepada anak perempuannya. Ayah Batak yang menerapkan pola asuh authoritative sebanyak 34 orang 
(16.9\%), ayah Batak yang menerapkan pola asuh authoritarian sebanyak 3 orang (1.5\%), dan ayah Batak yang menerapkan pola asuh permissive sebanyak 1 orang $(0.5 \%)$.

Ayah dari keluarga Tionghoa mayoritas menerapkan pola asuh authoritative kepada anak perempuannya. Ayah Tionghoa yang menerapkan pola asuh authoritative sebanyak 53 orang (26.4\%), ayah Tionghoa yang menerapkan pola asuh authoritarian sebanyak 7 orang (3.5\%) dan ayah Tionghoa yang menerapkan pola asuh permissive sebanyak 3 orang (1.5\%).

Ayah dari keluarga Manado mayoritas menerapkan pola asuh authoritative kepada anak perempuannya. Ayah Manado yang menerapkan pola asuh authoritative sebanyak 16 orang (8\%), ayah Manado yang menerapkan pola asuh authoritarian sebanyak 1 orang $(0.5 \%)$ dan ayah Manado yang menerapkan pola asuh permissive sebanyak 2 orang (1\%).

Ayah dari keluarga Sunda mayortias menerapka pola asuh authoritative kepada anak perempuannya. Ayah Sunda yang menerapkan pola asuh authoritative sebanyak 5 orang $(2.5 \%)$ dan tidak ada ayah Sunda yang menerapkan pola asuh authoritarian dan permissive.

kepada anak perempuan yaitu sebanyak 16 orang (51.6\%). Partisipan yang menerapkan pola asuh authoritarian kepada anak perempuannya berjumlah 11 orang (35.5\%), partisipan yang menerapkan pola asuh permissive kepada anak perempuannya berjumlah 4 orang (12.9\%). Kepada anak laki-laki, partisipan paling banyak menerapkan pola asuh permissive yaitu sebanyak 21 orang $(67.7 \%)$. Partisipan yang menerapkan pola asuh authoritative kepada anak laki-lakinya berjumlah 7 orang (22.6\%), partisipan yang menerapkan pola asuh authoritarian kepada anak laki-lakinya berjumlah 3 orang $(9.7 \%)$.

Berdasarkan pola asuh kepada anak perempuan berdasarkan suku bangsa, ayah dari keluarga Jawa mayoritas menerapkan pola asuh authoritative kepada anak perempuannya. Ayah Jawa yang menerapkan pola asuh authoritative sebanyak 66 orang (32.8\%), ayah Jawa yang menerapkan pola asuh authoritarian sebanyak 3 orang (1.5\%), dan ayah Jawa yang menerapkan pola asuh permissive sebanyak 7 orang $(3.5 \%)$.

Ayah dari keluarga Batak mayoritas menerapkan pola asuh authoritative kepada anak perempuannya. Ayah Batak yang menerapkan pola asuh authoritative sebanyak 34 orang (16.9\%), ayah Batak yang menerapkan pola asuh authoritarian sebanyak 3 orang (1.5\%), dan ayah Batak yang menerapkan pola asuh permissive sebanyak 1 orang $(0.5 \%)$.

Ayah dari keluarga Tionghoa mayoritas menerapkan pola asuh authoritative kepada anak perempuannya. Ayah Tionghoa yang menerapkan pola asuh authoritative sebanyak 53 orang (26.4\%), ayah Tionghoa yang menerapkan pola asuh authoritarian sebanyak 7 orang (3.5\%) dan ayah Tionghoa yang menerapkan pola asuh permissive sebanyak 3 orang (1.5\%).

Ayah dari keluarga Manado mayoritas menerapkan pola asuh authoritative kepada anak perempuannya. Ayah Manado yang menerapkan pola asuh authoritative sebanyak 16 orang $(8 \%)$, ayah Manado yang menerapkan pola asuh authoritarian sebanyak 1 orang $(0.5 \%)$ dan ayah Manado yang menerapkan pola asuh permissive sebanyak 2 orang (1\%).

Ayah dari keluarga Sunda mayortias menerapka pola asuh authoritative kepada anak perempuannya. Ayah Sunda yang menerapkan pola asuh authoritative sebanyak 5 orang $(2.5 \%)$ dan tidak ada ayah Sunda yang menerapkan pola asuh authoritarian dan permissive.

Berdasarkan pola asuh kepada anak laki-laki berdasarkan suku bangsa, ayah dari keluarga Jawa mayoritas menerapkan pola asuh authoritative kepada anak laki-lakinya. Ayah Jawa yang 
menerapkan pola asuh authoritative sebanyak 65 orang (32.3\%), ayah Jawa yang menerapkan pola asuh authoritarian sebanyak 1 orang $(0.5 \%)$, dan ayah Jawa yang menerapkan pola asuh permissive sebanyak 10 orang (5\%).

Ayah dari keluarga Batak mayoritas menerapkan pola asuh authoritative kepada anak lakilakinya. Ayah Batak yang menerapkan pola asuh authoritative sebanyak 33 orang (16.4\%), ayah Batak yang menerapkan pola asuh authoritarian sebanyak 1 orang $(0.5 \%)$, dan ayah Batak yang menerapkan pola asuh permissive sebanyak 4 orang (2\%).

Ayah dari keluarga Tionghoa mayoritas menerapkan pola asuh authoritative kepada anak lakilakinya. Ayah Tionghoa yang menerapkan pola asuh authoritative sebanyak 50 orang (24.9\%), ayah Tionghoa yang menerapkan pola asuh authoritarian sebanyak 2 orang (1\%) dan ayah Tionghoa yang menerapkan pola asuh permissive sebanyak 11 orang $(5.5 \%)$.

Ayah dari keluarga Manado mayoritas menerapkan pola asuh authoritative kepada anak lakilakinya. Ayah Manado yang menerapkan pola asuh authoritative sebanyak 12 orang (6\%), ayah Manado yang menerapkan pola asuh authoritarian sebanyak 2 orang (1\%) dan ayah Manado yang menerapkan pola asuh permissive sebanyak 5 orang $(2.5 \%)$.

Ayah dari keluarga Sunda mayortias menerapka pola asuh authoritative kepada anak lakilakinya. Ayah Sunda yang menerapkan pola asuh authoritative sebanyak 5 orang (2.5\%) dan tidak ada ayah Sunda yang menerapkan pola asuh authoritarian dan permissive.

Berdasarkan perbedaan pola asuh berdasarkan suku Bangsa, ayah dari keluarga Jawa mayoritas menerapkan pola asuh sama kepada anak laki-laki dan anak laki-laki. Ayah Jawa yang menerapkan pola asuh sama sebanyak 65 orang (32.3\%) dan ayah Jawa yang menerapkan pola asuh berbeda sebanyak 11 orang (5.5\%). Ayah dari keluarga Batak mayoritas menerapkan pola asuh sama kepada anak laki-laki dan anak laki-laki. Ayah Batak yang menerapkan pola asuh sama sebanyak 34 orang (16.9\%) dan ayah Batak yang menerapkan pola asuh berbeda sebanyak 4 orang $(2 \%)$.

Ayah dari keluarga Tionghoa mayoritas menerapkan pola asuh sama kepada anak laki-laki dan anak laki-laki. Ayah Tionghoa yang menerapkan pola asuh sama sebanyak 53 orang (26.4\%) dan ayah Tionghoa yang menerapkan pola asuh berbeda sebanyak 10 orang (5\%). Ayah dari keluarga Manado mayoritas menerapkan pola asuh sama kepada anak laki-laki dan anak lakilaki. Ayah Manado yang menerapkan pola asuh sama sebanyak 13 orang $(6.5 \%)$ dan ayah Manado yang menerapkan pola asuh berbeda sebanyak 6 orang (3\%). Ayah dari keluarga Sunda mayoritas menerapkan pola asuh sama kepada anak laki-laki dan anak laki-laki, yaitu sebanyak 5 orang $(2.5 \%)$ dan tidak ada ayah Sunda yang menerapkan pola asuh berbeda.

Pada penelitian ini, hasil yang didapatkan adalah mayoritas responden menerapkan pola asuh yang sama kepada anak perempuan dan anak laki-laki (84.6\%). Para ayah yang menerapkan pola asuh yang sama ini sebagian besar menerapkan pola asuh authoritative baik kepada anak perempuan maupun anak laki-laki (92.9\%). Hal ini ditemukan pada kasus pembanding dimana seorang ayah mampu menerapkan pola asuh authoritative sama kepada anak perempuan dan anak laki-laki.

Responden yang menerapkan pola asuh berbeda kepada anak perempuan dan anak laki-laki memiliki hasil yang hampir sesuai dengan kasus yang ditemukan. Responden penelitian menerapkan pola asuh permissive kepada anak laki-laki dan authoritative kepada anak perempuan. Pada analisa tambahan, sebagian besar dari responden ini berasal dari keluarga Tionghoa dan Jawa. 
Hasil dari penelitian ini menunjukkan bahwa ayah dari keluarga modern di kota besar pada jaman sekarang sudah tidak lagi menerapkan pola asuh berbeda kepada anak perempuan dan anak laki-laki.

Hal ini sejalan dengan penelitian oleh Ranson bahwa para ayah sudah meningkatkan partisipasi mereka dalam pengasuhan anak. Gambaran ayah yang terlibat yang baru sudah berbeda dibandingkan gambaran ayah yang terlibat pada masa lampau dalam beberapa aspek penting seperti; ayah hadir dalam kelahiran anak; terlibat ketika anak-anak masih bayi tidak hanya ketika mereka sudah dewasa; berpartisipasi dalam pengasuhan anak sehari-hari, tidak hanya dalam permainan dan terlibat dengan anak perempuan mereka sama seperti anak laki-laki mereka (Ranson, 2015).

Pendidikan ayah juga memberikan pengaruh dimana $48.3 \%$ dari responden merupakan lulusan S1, dengan lebih tingginya pendidikan ayah pada masa sekarang, maka ayah sudah tidak lagi mengikuti nilai nilai budaya kuno yang membedakan antara anak perempuan dan anak lakilaki. Berdasarkan data partisipan yang terkumpul, lebih banyak istri dari para responden yang merupakan lulusan S1 dibandingkan dengan total ayah lulusan S1. Hal ini dapat memberikan pemikiran kepada ayah bahwa anak perempuan dan anak laki-laki memiliki kesempatan sama dalam pendidikan dan lain-lain.

Hal ini sejalan dengan penelitian oleh Ranson dimana perubahan pada pola asuh ayah beriringan oleh tanda-tanda perubahan lainnya terutama pergeseran tingkat wacana popular dan ideology. Orang-orang yang terpelajar setuju bahwa gambaran dominan mengenai ayah sebagai 'breadwinner' sudah berubah dengan gambaran budaya mengenai ayah yang juga terlibat dengan anak-anak mereka (Ranson, 2015).

\section{KESIMPULAN DAN SARAN}

Berdasarkan analisa data dari penelitian ini, ayah yang menjadi responden penelitian ini sudah menerapkan pola asuh yang sama antara anak perempuan dan anak laki-laki walaupun ayah berasal dari keluarga patrilineal. Sebanyak $84.6 \%$ dari total responden menerapkan pola asuh yang sama kepada anak perempuan dan anak laki-laki, dari jumlah ayah ini $92.9 \%$ ayah menerapkan pola asuh authoritative kepada baik anak perempuan dan anak laki-laki.

Namun terdapat $15.4 \%$ dari total responden menerapkan pola asuh yang berbeda kepada anak perempuan dan anak laki-laki. Dari 31 ayah yang menerapkan pola asuh berbeda ini, $51.6 \%$ menerapkan pola asuh authoritative kepada anak perempuannya dan $67.7 \%$ menerapkan pola asuh permissive kepada anak laki-lakinya. Sebagian dari para ayah yang menerapkan pola asuh berbeda kepada anak perempuan dan anak laki-laki berjumlah 11 orang ayah dari keluarga Jawa dan 10 orang ayah dari keluarga Tionghoa.

Saran yang dapat diberikan dari penelitian ini adalah karena penelitian ini dilakukan di Jakarta dengan responden yang berasal dari kota-kota besar lainnya selain Jakarta, seperti Bogor, Tangerang dan Bekasi. Hasil yang didapat di penelitian ini dapat disebabkan oleh asimilasi budaya di kota besar yang lebih modern dan nilai-nilai patrilineal yang sudah agak memudar. Untuk penelitian selanjutnya, disarankan dapat dilakukan dengan lingkup sampel yang lebih besar dan tidak terbatas pada ayah-ayah di kota besar saja.

Penelitian ini diharapkan dapat memberikan pengetahuan lebih dalam lagi kepada ayah dan ibu mengenai macam-macam pola asuh yang ada, serta manfaat dan kekurangan dari setiap pola asuh yang diterapkan. Kepada ayah dan ibu di keluarga patrilineal yang masih melakukan perbedaan pola asuh kepada anak laki-laki dan anak perempuan, diharapkan dengan membaca penelitian ini untuk lebih mengerti tentang kesetaraan anak perempuan dan anak laki-laki dan 
di masa sekarang perbedaan pola asuh antara anak perempuan dan anak laki-laki sudah tidak begitu diterapkan.

\section{Ucapan Terima Kasih}

Penelitian ini didukung oleh guru dan staff dari SMAN X, pengerja dari Perkumpulan Y yang telah membantu dalam pelaksanaan pengumpulan data bagi penelitian ini. Peneliti mengucapkan terima kasih kepada para ayah yang sudah bersedia menjadi partisipan dalam penelitian ini. Peneliti berterima kasih kepada dosen-dosen dari Fakultas Psikologi Universitas Tarumanagara yang sudah memberikan masukan dan komentar yang membangun penelitian ini menjadi lebih baik. Peneliti juga ingin berterima kasih kepada rekan-rekan yang sudah membantu memberikan masukan dan dukungan selama pengerjaan penelitian ini.

\section{REFERENSI}

Aninda, R.N. (2013). Nilai Anak Perempuan pada Keluarga Batak Ditinjau Dari Ibu Dewasa Awal dan Dewasa Madya. Jurnal Ilmiah Mahasiswa Universitas Surabaya,2.

Cohen, L., Manion, L., \& Morrison, K. (2007). Research Methods in Education. New York, NY: Routledge

Floyd, B. (2003). Patrilineal Family Values, Family Planning and Variation in Stature Among Taiwanese Six-year-olds. Journal of Biosocial Science, 35, 369-384.

Ranson, G. (2015). Fathering, masculinity and the embodiment of care. New York, NY: Palgrave Macmillan.

Ruether, Rosemary Radford. (2007). Encyclopedia of Sex and Gender. Vol. 3. Detroit: Macmillan Reference USA.

Sadiq Sangawi, H., Adams, J., \& Reissland, N. (2015). The Effects of Parenting Styles on Behavioral Problems in Primary School Children: A Cross-Cultural Review. Asian Social Science, 11(22). doi: 10.5539/ass.v11n22p171

Sánchez, M. (2017). Fathering within and beyond the failures of the state with imagination, work and love. Rotterdam: Sense Publishers.

Sigelman, C.K. \& Rider, A. (2012). Life span human development. Belmont, CA : Cengage Learning

Suliyati, T. (2002). Studi Gender pada Masyarakat Tionghoa di Daerah Pecinan Semarang. Fakultas Sastra Universitas Diponegoro

Suliyati, T (2002). Pemahaman Masyarakat Cina terhadap Gender. Fakultas Sastra Universitas Diponegoro 